\title{
usefulness of Fenbufen in long term therapy of chronic rheumatoid arthritis
}

\author{
Fenbufen の慢性関節リウマチに対する
}

長期投与試験

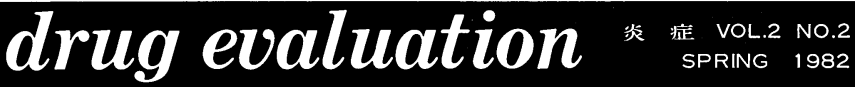

長屋郁郎・原田志朗・稲垣善幸 ・ 小西陽一・国島康夫・柴田義守*
非ステロイド系抗炎症剂の効果と安全性，すなわち有 用性の検討には，一定の評価が確立している基準薬剂を 比較対照薬剂に設定して，二重盲検法により行うことが 多く, かつ現実的でもある。乙かしながら，この種の薬 剂は慢性関節リウマチや変形性関節症などの治療に用い られることが多く，また疾患の特性からみて長期間にわ たり投与しつつける場合が多い。特に慢性関節リウマチ に対する有用性の検索には，その病態より鑑みて必然的 に長期投与によってのみ有用性が判明するともいえる。

この観点より，筆者ら*は，有用性が数々の二重盲検 試験によりすでに報告されている(1 4) フェンブフェンの 慢性関節リウマチに対する長期投与試験を実施した。

フェンブフェン（図 1) は，アメリカレダリー研究所 により開発された非ステロイド系抗炎症剂であり，その 抗炎症作用は数々の前臨床, 臨床試験により実証されて いる。また，本剤の特徵は，この種の薬剂では日本では ごめて登場した pro-drug である ${ }^{5)}$ 。すなわち，慢性関 節リウマチなど長期にわたり投与する場合には，その胃 腸壁に対する直接刺激などが少ないといわれており，胃 腸障害などの副作用の軽減が期待できる.

\section{* 本欄の執筆者}

長屋郁郎：国立名古屋病院整形外科

原田志朗：中部労災病院整形外科

稲垣善幸 : 安城更生病院整形外科

小西陽一：社会保険中京病院整形外科

国島康夫：稲沢市民病院整形外科

柴田義守：海南病院整形外科

\section{本研究の参加施設（順不同）}

国立名古屋病院（整形外科），社会保険中京病院(整 形外科), 愛知県済生会病院 (整形外科), 中部労災 病院 (整形外科), 名城病院 (整形外科), 国立療盖 所東名古屋病院 (整形外科), 名鉄病院(整形外科), 公立陶生病院 (整形外科), 安城更生病院 (整形外 科), 加茂病院 (整形外科), 刚谷豊田病院 (整形外 科), 常滑市民病院（整形外科），一宮市立市民病院 (整形外科)，稲沢市民病院（整形外科），昭和病院 (整形外科), 海南病院（整形外科） 4-(4-biphenylyl)-4-oxobutyric acid

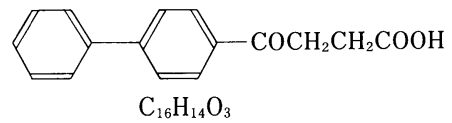

図 1 Fenbufen

\section{対象と方法}

(1) 対 象

昭和54年10月から56年 3 月までに 16施設*に打いて治 療した classical または definite の慢性関節リウマチの 患者 100 例を対象とした。

(2) 投与方法

フェンブフェンは，原則として 1 日 $600 \mathrm{mg} を$ 毎食後 3 分割投与した。併用薬剤は特に禁止しなかったが，他の 非ステロイド系抗炎症剂の併用は原則として行わないこ ととした。

(3) 投与期間

本剂の耐薬性を検討するため， 1 年以上を目標とし た。

(4) 観察項目および観察日

観察項目としては，ARA 基準に従った。すなわち, 朝のこわばり持続時間, 握力, 赤沈值, 関節指数を記録 し，ランスバリー指数を算出した。 その活か各観察日ご とに開始日と比較した総合判定を求めた。安全性の検索 には, 副作用症状の調査とともに臨床検査を毎月行っ た. 患者の観察は 2 週間に 1 回は実施し，かつ 3 カ月に 1 回は図 2 に示寸調查用紙に記入した.

\section{結 果}

(1) 対 象

100 例の患者を対象として試験を開始したが，試験期 間終了時に和いて投薬期間が 1 年に満たない 21 例は集計 より除外し，79例を集計対象とした（表 1 ）.

79 例のらち，4 例は試験開始後 1 力月以内に発疹がみ られ，フェンブフェンの投与を中止したので効果の評価 から除外した。 しかし副作用例の検討には組み込えだ. 
表 1 対象患者数

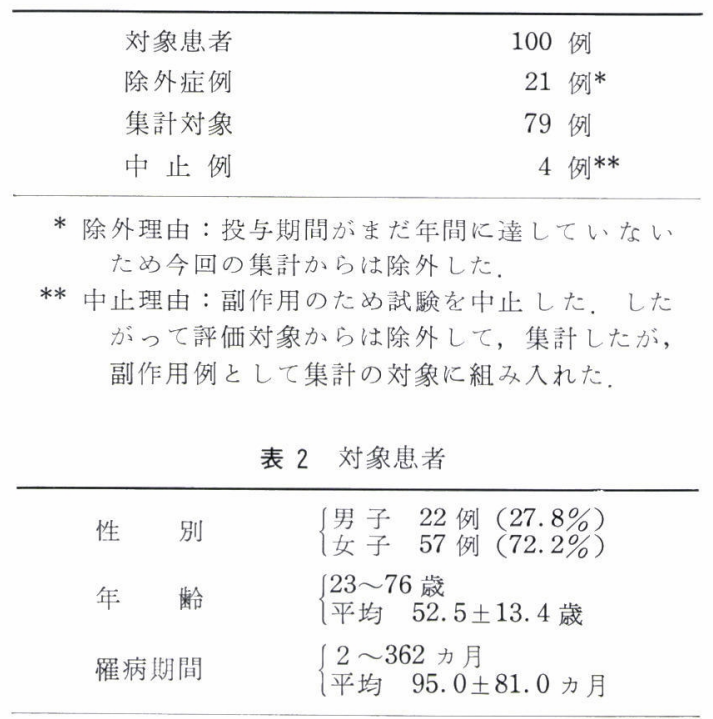

表 3 前治療薬剂

\begin{tabular}{l|r|r}
\hline \multicolumn{1}{c|}{ 前治療薬剤 } & 症例数 & $(\%)$ \\
\hline indomethacin & 25 & 31.6 \\
ibuprofen & 10 & 12.7 \\
aspirin & 8 & 10.1 \\
diclofenac & 6 & 7.6 \\
phenylbutazone & 6 & 7.6 \\
ketoprofen & 6 & 7.6 \\
naproxen & 5 & 6.3 \\
aluminium flufenamate & 3 & 3.8 \\
flurbiprofen & 3 & 3.8 \\
mefenamic acid & 2 & 2.5 \\
alclofenac & 2 & 2.5 \\
clofezone & 2 & 2.5 \\
tiaramide hydrochloride & 1 & 1.3 \\
\hline \multicolumn{1}{c|}{ 計 } & 79 & 100.0 \\
\hline
\end{tabular}

対象患者は，男子 22 例 $(27.8 \%)$ ，女子57例 (72.2\%) で, 年㱓は平均 $52.5 \pm 13.4$ 歳（23〜76歳）であった。慢 性関節リウマチの罹病期間は，平均 $95.0 \pm 81.0$ 力 $(2$ 〜362力月）であった（表 2 ）。本試験に組又込む前に投 与されていた薬剤は, indomethacin 25例 (31.6\%), ibuprofen 10例 $(12.7 \%)$, aspirin 8 例 (10.1\%), diclofenac sodium 6 例 $(7.6 \%)$ などであった（表 3 ).

フェンブフェンとともに僧用された薬剤のらち, ステ ロイドを用いた症例は 15 例あり，関節内投与は 9 例 (11. $4 \%)$ ，経口投与は 6 例 $(7.6 \%)$ であった。ただし， これらの投与は，関節内注入の場合 1 力月当り $1 \sim 2$ 回, 経口投与の場合は, プレドニゾロンとして 1 日当り $5 \mathrm{mg}$ 以下の維持量であった（図 3 )。胃腸薬の併用は

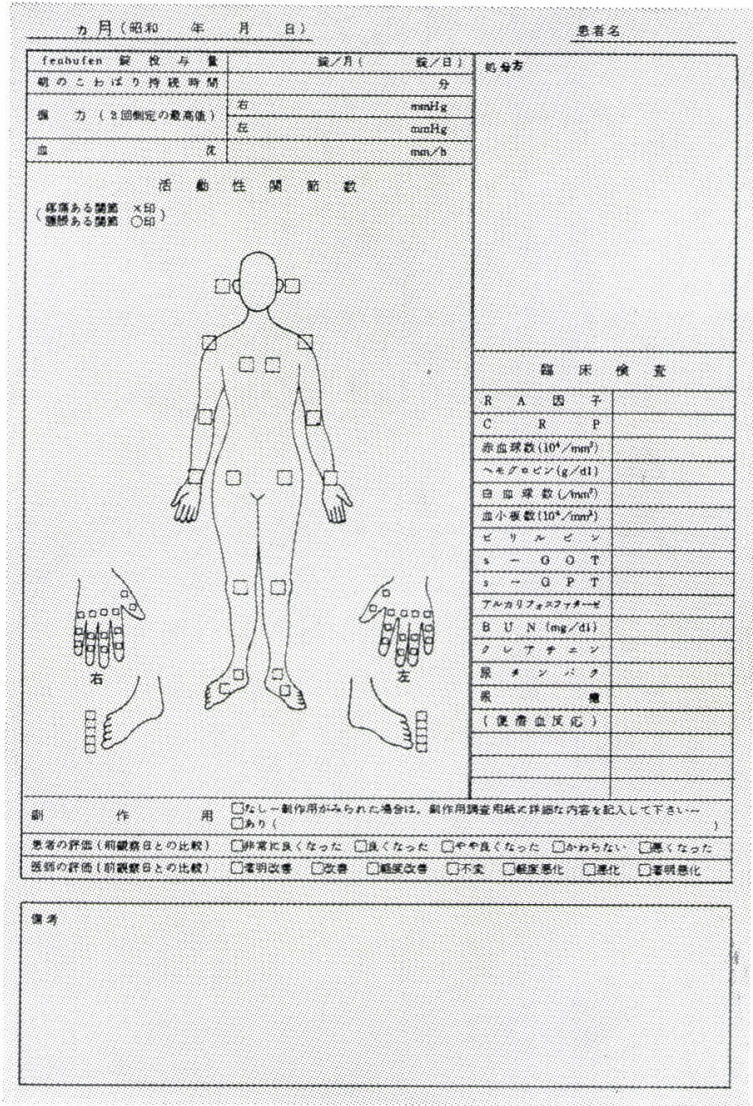

図 2 調查用紋

表 4 評価項目の変動（観察日別）

\begin{tabular}{|c|c|c|c|c|c|}
\hline 項 目 & 開始時: & \begin{tabular}{|l|}
3 力月 \\
後
\end{tabular} & \begin{tabular}{|l|}
6 力月 \\
後 \\
\end{tabular} & $\mid$\begin{tabular}{|l}
9 力月 \\
後
\end{tabular} & $\begin{array}{l}12 \text { 力月 } \\
\text { 後 }\end{array}$ \\
\hline $\left.\begin{array}{l}\text { Lansbury activity } \\
\text { index }(\%)\end{array}\right\}$ & 64.1 & 62.1 & 57.5 & 56.1 & 57.3 \\
\hline $\begin{array}{c}\text { 朝のこわばり持続 } \\
\text { 時間 }\end{array}$ & 95.9 & 103.5 & 85.8 & 83.7 & 84.4 \\
\hline 血沈值 $(\mathrm{mm} / \mathrm{hr})$ & 52.6 & 43.0 & 40.5 & 39.7 & 39. \\
\hline 関節指数 & 61.1 & 54.1 & 49.0 & 45.8 & 44.9 \\
\hline 握 力 $(\mathrm{mmHg})$ & 132.3 & 131.2 & 126.7 & 132.6 & 131.0 \\
\hline
\end{tabular}

43例 (54.4\%) であった。

(2) 成 績

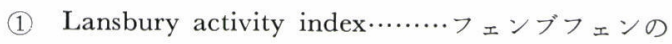
抗リウマチ効果としてランスバリー指数を算出した。試 験開始時は平均 $64.1 \%$ であったが，3 月月後 $62.1 \%, 6$ 力月後 $57.5 \%, 9$ 力月後 $56.1 \%, 12$ 力月後 $57.3 \%$ を示し た（表 4,㘠 4).

(2) 朝のこわばり持続時間………朝のこわばり持続時 間は, 開始時では平均 95.9 分であり, 3 力月後 103.5 分 に上昇したが， 6 力月後 85.8 分， 9 力月後 83.7 分， 12 力 月後84.4分となり，6 月以降はほぼ一定した（表 4 , 
表 5 有 効 率

\begin{tabular}{c|c}
\hline 評価時期 & 改善率 \\
\hline 3 力月後 & $42.6(\%)$ \\
6 力月後 & 58.2 \\
9 力月後 & 67.2 \\
12 月月後 & 72.1 \\
\hline
\end{tabular}

表 6 副 作 用

$\left.\begin{array}{lc}\hline \text { 副作用なし } & 73 \text { 例 }(92.5 \%) \\ \text { 胃腸障害(継続投与可能症例) } & 2 \text { 例 }(2.5 \%) \\ \text { 発 疹 (中止例) } & 4 \text { 例 }(5.1 \%)\end{array}\right\} 7.6 \%$

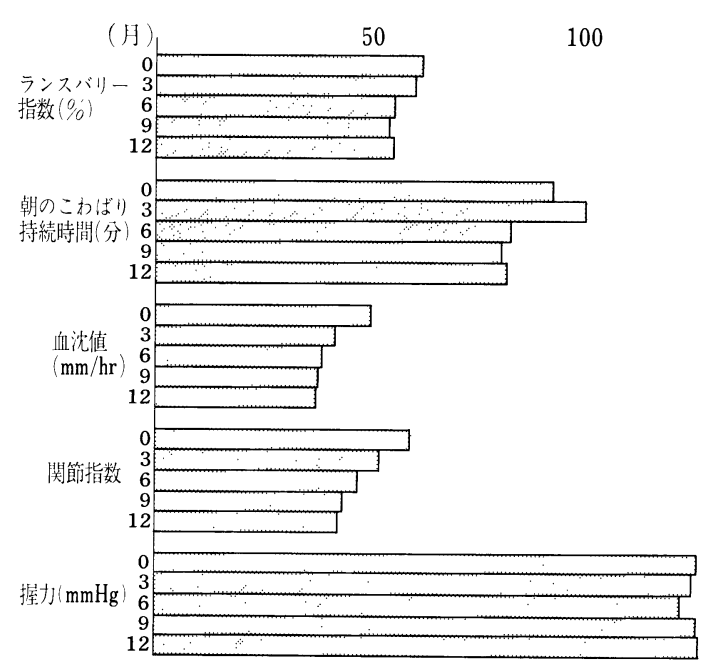

図 4 評価項目の変動

図 4).

(3) 血沈值………血沈 1 時間值は, 開始時飞平均 52.6 $\mathrm{mm}$ であり， 3 力月後 $43.0 \mathrm{~mm}, 6$ 力月後 $40.5 \mathrm{~mm}, 9$ カ月後 $39.7 \mathrm{~mm}, 12$ 力後 $39.0 \mathrm{~mm}$ となった。 したがっ て 3 力月後では $9.6 \mathrm{~mm}, 12$ 力後では $13.6 \mathrm{~mm}$ の改善 をみた（表 4, 図 4).

(4) 関節指数……...関節指数は, 開始時 61.1 であり, 3 力月後 $54.1,6$ 力月後 $49.0,9$ 力月後 $45.8,12$ 力月後 44.9となった（表 4, 図4).

(5) 症状のコントロール………本剤の投与開始時を基 準として, 症状が安定しているかどうかを各観察日に評 価した結果 (有効率), 3 力月後 $42.6 \%$ の患者に症状の 安定が2られ，6力月後 $58.2 \%, 9$ 力月後 $67.2 \%, 12$ 力 月後 $72.1 \%$ であった（表 5 , 図 5 ).

(6) ステロイドの離脱………試験開始時にステロイド 剂の併用を行っていた症例は15例であった。この15例を 追跡したところ，ステロイド剂の離脱ができた時期は試 験開始後 3 力月, 6 力月後に各 1 例, 7 力月後 2 例, $8,10,11$ 力月後に各 1 例, 合計 7 例に打いて併用を中止 することができた.

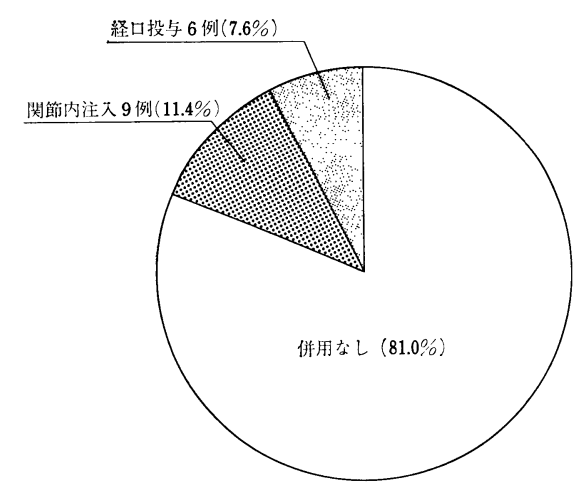

図 3 ステロイド併用症例

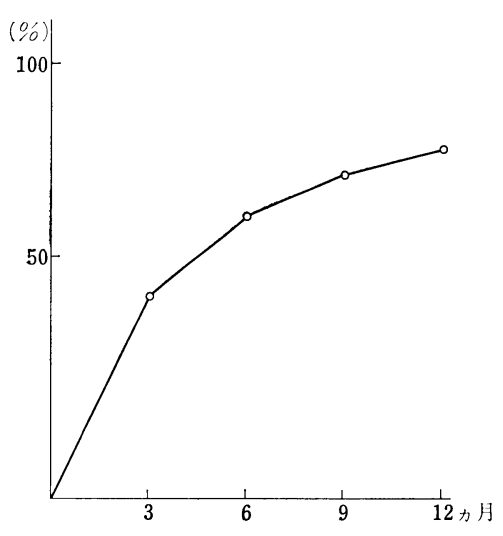

図 5 改善率

(7) 副作用………副作用は胃腸障害 2 例 $(2.5 \%)$, 発 疹 4 例 $(5.1 \%)$ で合計 6 例 (7.6\%) であった.

胃腸障害は 2 例とも軽度で試験開始後 7 日目と 6 カ月 目にみられたが，フェンブフェンの投与をそのままつづ 汀るらちに自然消失し, 本剤の 1 年間投与が可能な症 例であった（表 6 ).

発疹の 4 例は，いずれも試験開始後10２0日の間にみ られ,フェンブフェンの投与を中止したところ消失し た。ちなみに, これらの症例において臨床検査值の異常 は認められなかった。

(8) 臨床検査值…………ずれの検査時点に抢いても 異常值を示す症例は認めなかった。な和, 実施した検査 事項は肝機能検査 (GOT, GPT, アルカリフォスファ ターゼ, ビリルビン), 血液像 (赤血球数, 白血球数, 血小板数, へモグロビン值), 腎機能検查 (BUN, 尿蛋 白，尿糖，クレアチニン值），便潜血反応である。

\section{考察}

薬剂の効果を判定するには，一定の有用性が確立した 基準薬剤を比較対照に設定し，二重盲検法により検索す る方法が現在多く行われている。 しかし，その対象とな る疾患が慢性疾患の場合には，比較的長期間にわたり臨 床的検討を行う必要がある，筆者らが今回慢性関節リウ 
マチに対するフェンブフェンの長期投与試験を実施した のもこのような理由である.

フェンブフェンは, 非ステロイド系抗炎症剤であり, わが国に打いてはじめて登場した pro-drug である5). 本剂の特徵は, フェンブフェン自体が非活性であるた め, 既存の非ステロイド系抗炎症剂にくらべ，内服によ る直接的な胃腸障害が大幅に低減できるということであ り，また，内服後，肝に打いて代謝活性化された 4-biphenylylacetic acid が抗炎症作用を発揮し，抗りウマ チ効果をあらわすといわれることである。事実, 本剤 は, 各種の非ステロイド系抗炎症剂との二重盲検試験が 実施, 報告されており, その有用性, 特に安全性は高く 評価されている1 4).

試験の計画を協議した時点では，100症例の慢性関節 リウマチ患者に対して 1 時間以上の投与を目標とした が，対象患者の選択や参画各施設の事情などにより試験 期間終了時に 21 例が 1 年間の投与期間に達していなかっ た. したがって79例について集計し評価を行った.

79例のらち，1年間またはそれ以上フェンブフェンの 投与が可能であったのは，75例 (94.9\%) であり，4 例 (5.1\%) は，途中で副作用がみられ，中止せざるをえな かった。 また, 症状のコントロールが成功した症例は, 1 年後の観察時点に拈いて72.1\%という高い值を示し た.このように $94.9 \%$ 症例が 1 年間にわたり投与継続 できたことは，フェンブフェンのきわめて高い抗リウマ チ効果と安全性を実証できたといえる.

一般に抗リウマチ効果というと, 一時的な炎症症状の 鎮静化を云々したくなるが，慢性関節リウマチのように その根治療法が定かでない疾患の場合には，いかに各患 者個々に適した抗炎症剂を選択し症状の長期的コントロ ールを行らかが重要である。

今回の評価に当っては，ARA 基準を採用し，慢性関 節リウマチの各症状を数量化して客観的に検索してみ たそその結果，いずれの症状に执いても 3 カ月後または 遅くとも 6 力月後には軽隇し，かつそれが持続してお り，抗リウマチ作用が認められた。特に血沈值に打いて は開始日の平均が $52.6 \mathrm{~mm} / \mathrm{hr}$ であったのが， 3 力月後 には $43.0 \mathrm{~mm} / \mathrm{hr}$ となり，最終的には $39.0 \mathrm{~mm} / \mathrm{hr}$ とな っていた。 また関節指数に打いても61.1より44.9亿軽減 したことも注目できる。これらの炎症症状の改善は，各 担当医師の評価にも反映しており，3 月月後 $42.6 \%, 6$ 力月後 $58.2 \%, 9$ 力月後 $67.2 \%, 12$ 力月後 $72.1 \%$ と評価 されていることと一致していた。一方，ステロイド斉の 離脱に成功した症例は，15例中 7 例 $46.7 \%$ であった。 こ のようにステロイド剂の離脱を目的とする場合にも，個 個の対象患者に適した抗リウマチ作用の強い薬剤によ り，機をみて行らことが一方法と考兄られるかもしれな い.
副作用は79例中 6 例 $(7.6 \%)$ にみられた。特に胃腸障 害は 2 例 $(2.5 \%)$ と少なく，かつ 2 例ともフェンブフ ェンの 1 年間継続投与が可能であったことは高く評価で きる。このことは, 本試験開始前に患者の過半数に用い られていた薬剤が indomethacin, ibuprofen, aspirin, diclofenac, phenylbutazone, ketoprofenなどであり，そ の時期より患者の過半数 (54.4\%) が胃腸薬を併用して いたことも影響していると思われるが，フェンブフェン の pro-drug としての特長，すなわち胃腸障害が少ない といらことを示していると思われる。発疹の 4 例は, 試 験途中で投与を中止したが，全例高度のものではなく， 投与中止により消失した。なお，臨床検査值の異常例は みられなかった。

以上のことから，今回の長期投与試験によりフェンブ フェンは, 慢性関節リウマチの治療においてきわめて有 用性の高い非ステロイド系抗炎症剂であると結論づけら れた。また，いまだ 1 年間の投与に至っていない症例を 含め, 今回の長期投与試験をより長期間継続し，機会を みて再び報告したいと考える。

\section{まとめ}

(1) 慢性関節リウマチに対するフェンブフェンの長期 投与試験（ 1 年間）を実施した.

(2) 79 例中75例 $(94.9 \%)$ が 1 年間投与可能であっ た.

(3) 評価項目としてとりあげたいずれの症状において も, 3 力月後には鎮静化しており，かつその後も症状の コントロールに成功した。

(4) $72.1 \%$ 患者に症状の安定化がみられた.

(5) 副作用は 6 例 $(7.6 \%)$ にみられた.

なお, 本研究は, XV International Congress of Rheumatology (1980) Paris にて概要を発表した.

\section{文 献}

1）日本リウマチ薬效検査委員会：慢性関節リウマチ に扣ける Fenbufen の薬效検定。リウマチ18: 56-12, 1978.

2）塩川優一・他：慢性関節りウマチに対するFenbufen の多施設二重盲検比較試験一アスピリンを 対照薬とする長期投与試験一. 医学のあゆみ 104: 614-638, 1978 .

3）青木虎吉・他：卒形性膝関節症に対する Fenbufen の二重盲検比較試験成績。医学のあゆみ 103: 110-126, 1977.

4）伊勢亀冨士朗・他：変形性膝関節症に対するナパ ノール錠の臨床的検討一多施設二重盲検比較対照 臨床試験成績一. 臨牀と研究 57：953-962,1980.

5) Mizushima, Y.: Basic and clinical studies on Pro-drugs of Non-Steroid anti-inflammatory drugs. XV International congress of rheumatology, 1980, Paris. 